\title{
Statistical study of combustion characteristics and optimal operation factor determination in an emulsion burner fuelled with vegetable oils
}

Y. Arroyo, ${ }^{* 1}$ M.A. Sanz-Tejedor, ${ }^{* 1} J$. San José ${ }^{2}$ and L.A. García-Escudero ${ }^{3}$

${ }^{1}$ Department of Organic Chemistry, ITAP, School of Industrial Engineering, University of Valladolid, Paseo del Cauce 59, 47011 Valladolid, Spain

${ }^{2}$ Department of Energy Engineering and Fluid Mechanics, ITAP, School of Industrial Engineering, University of Valladolid, Paseo del Cauce 59, 47011 Valladolid, Spain; ${ }^{3}$ Department of Statistics and Operational Research, Faculty of Science, University of Valladolid, Paseo de Belén, 7, 47011 Valladolid, Spain

Keywords: vegetable oils, emulsion burner, combustion, PCA, ANOVA.

Paper type: Primary Research 


\section{Abstract}

This work experimentally investigates the combustion characteristics of refined soya, sunflower and rapeseed vegetable oils and, by means of statistical techniques, determines the optimal operating factors of an emulsion burner to obtain the best combustion performance and low pollutant emissions. Given the high dimensionality of the study, the PCA provides a descriptive study of the variables involved in the combustion process and of the physicochemical properties of the vegetable oils so as to establish the correlations between them. ANOVA was then performed to identify which factors (type of vegetable oil, fuel flow, and airflow), as well as any possible interactions, have the greatest impact on the combustion results (performance as well as $\mathrm{CO}_{2}$, CO, NOx, CxHy and SOx emissions). ANOVA results showed that almost all of the factors and their interactions were significant, which makes it essential to analyse the interaction plots to see the optimal combinations of levels. This study showed that fuel flow rate was quite an important factor affecting combustion characteristics, that the type of vegetable oil influenced CxHy emissions, and that the airflow rate displayed no clear trend. Furthermore, the best combustion performance coupled with pollutant emissions that were below the lowest limits established by current legislation were achieved for a combination of maximum fuel flow and minimum airflow rates, with soya exhibiting the best performance. In general, good combustion performances were obtained with extremely low NOx emissions, and SOx emissions were not detected in any of the combustion experiments performed. 


\section{Introduction}

The growing demand for energy, the environmental impact of fossil fuels, and energy supply security are the main worries in today's energy scene. Within this context, the use of vegetable oils (VOs) as a potential source of energy for heating purposes, has grown in popularity as an alternative to fossil fuels [1], due to the fact they are renewable sources, are eco-friendly, non-toxic and biodegradable. One key aspect in the composition of VOs is their virtually negligible sulphur and nitrogen content, which contributes significantly towards curbing emissions of $\mathrm{SO}_{\mathrm{x}}$ and $\mathrm{NOx}$, thus avoiding any harmful environmental impact. Furthermore, production of VOs has spread worldwide and many countries are now producing different types of VOs, depending on their climate, which might contribute towards the energy sustainability of areas where fossil resources are unavailable.

The main drawback of using VOs as biofuels in domestic and industrial boilers is their high viscosity and low volatility, which hinders the atomization process and might lead to incomplete combustion and even carbon deposits in the combustion chamber. One solution to this problem is to chemically transform VOs in order to produce biodiesel, which has been widely documented in the literature [2]. However, this method evidences certain drawbacks such as: long reaction times, high energy consumption during preparation and subsequent purification processes [3] as well as the large amount of glycerol obtained as a by-product of little added value [4]. Another strategy widely used by a number of researchers to reduce the viscosity of VOs involves blending them with lower viscosity oil derivatives. In this regard, San José et al. used a conventional facility equipped with a mechanical pulverization burner to burn blends of diesel fuel with a range of VOs such as sunflower (SfO) $[5,6]$ soya $(\mathrm{SyO})[7,8]$ and rapeseed oil (RpO) [9]. Using injection pressures between $1 \times 10^{6}$ and $1.4 \times 10^{6} \mathrm{~Pa}$ and different VO- 
diesel fuel blends (up to $40 \%$ in VO), combustion performances above $85 \%$ and NOx emissions below 53 ppm were attained by the authors. In another study [10], the combustion of diesel fuel-animal fat blends, not apt for human consumption, in a residential oil burning facility was carried out. The best combustion performances were obtained for blends with $10 \%$ animal fat, using an injection pressure of $1 \times 10^{5} \mathrm{~Pa}$. Daho et al. [11] studied the performance and emissions of different coconut vegetable oil (CnO)-diesel fuel blends in a domestic boiler, and reported that $\mathrm{CO}, \mathrm{NOx}$ and $\mathrm{CO}_{2}$ emissions were the same for all blends studied, when the boiler worked at an injection pressure of $2 \times 10^{6} \mathrm{~Pa}$. Jiru et al. [12] evidenced that it is possible to burn blends of SyO degummed fuel oil (20\% SyO) in an unmodified commercial burner. The combustion of blends of palm oil (PlO)-diesel fuel in an industrial oil burner with and without secondary air was studied by Mohd Jaafar et al. [13]. The lowest emissions of CO and NOx were obtained with blends containing 25\% PlO. Recently, Esarte et al. [14] studied the performance and emissions of different blends of fossil fuels with renewable fuels such as VOs and their fatty acid methyl esters (FAMEs) in a domestic condensing boiler.

Despite their high viscosity, direct combustion of VOs in commercial burners can be carried out by simply correctly adjusting the device parameters. Good examples of this are the studies by Vaitilingom and Daho, who analysed the combustion of RpO [15] and CnO [16], respectively, in a modified fuel oil burner using injection pressures of $2.8 \times 10^{6} \mathrm{~Pa}$ and preheating the VOs $\left(\mathrm{T} \geq 125^{\circ} \mathrm{C}\right)$. By applying these conditions, quite low CO emissions ( $\leq 13 \mathrm{ppm})$ and high combustion efficiencies (around 93\%) were achieved. Combustion of raw SyO, pre-heated to $70-80{ }^{\circ} \mathrm{C}$, in a $2 \mathrm{MW}$ pilot boiler has also been studied [17]. The CO and NOx emissions obtained were similar to those of diesel fuel (250 $\mathrm{mg} \cdot \mathrm{m}^{-3}$ and $145 \mathrm{mg} \cdot \mathrm{m}^{-3}$, respectively). 
One crucial issue to be taken into account for the correct combustion of VOs is the type of burner used, since it must be suitable for high viscosity liquid fuels. In this regard, Holt et al. [18] used a multi-fuelled burner to perform the combustion of crude and semi-refined $\mathrm{CnO}$, although high polluting gases were obtained. Recently, Józsa et al. [19] studied the combustion of raw RpO in a lean premixed pre-vaporized burner, although stable combustions were limited by inadequate atomization. Giovannoni et al. [20] assessed the performance of SfO in a small-scale flat flame regenerative combustion chamber. Despite the viability of the experiment, obstruction problems in the combustion chamber channels were found 40 minutes into operation. San José et al. [21] showed that the use of a low-pressure auxiliary air fluid pulverization burner is the best option for burning liquid fuels, such as VOs, with a kinematic viscosity between 26 and $112 \mathrm{~mm}^{2} \cdot \mathrm{s}^{-1}$ (at $50{ }^{\circ} \mathrm{C}$ ). Using this burner, which operates with an injection pressure of $1 \times 10^{5} \mathrm{~Pa}$, the authors carried out the combustion of VOs, rich in unsaturated fatty acids (SfO, RpO, SyO) as well as $\mathrm{CnO}$ and $\mathrm{PlO}$ with a high content of saturated fatty acids [22,23]. A relationship between the VOs' degree of unsaturation and certain combustion parameters was established in these works, which found that CO emissions decreased and that combustion efficiencies increased as the degree of VO unsaturation rises [23]. They also achieved NOx emissions below 46 ppm in all the experiments performed, regardless of the VO used. Recently, this research group studied the atomization and combustion processes of PlO in the same emulsion burner. They found that the greater the spray cone angle, the less the spray tip penetration length and, in most of the tests performed, the lower the spray cone angle the greater the combustion performance [24].

In light of the above information, the combustion results of VOs depend on many factors such as the uniqueness of their fatty acid profile, the type of burner used and the 
operating conditions. Therefore, the burning characteristics of VOs still require exhaustive research in order to understand how they are affected by different factors. By applying appropriate statistical tools, the aim of this work is to analyse the combustion results of refined SyO, SfO and $\mathrm{RpO}$ in an emulsion burner, modifying three fuel flows and three secondary airflows. First a descriptive study is carried out applying a PCA technique on the combustion variables and on the physicochemical properties of VOs so as to establish possible correlations between them. Subsequently, from a more inferential approach, an ANOVA analysis of the combustion results is then carried out to establish the significance of the different operating factors as well as their possible interactions on emissions $\left(\mathrm{CO}_{2}, \mathrm{CO}\right.$, $\mathrm{NOx}$ and $\left.\mathrm{CxHy}\right)$ and combustion performance. Finally, the optimal operating conditions for the burner, in terms of performance and emissions, are also established.

\section{Materials and methods}

\section{Materials}

The refined SfO, SyO and RpO used in this work are commercially available and all of them were used without prior purification. The elemental composition and physicochemical properties of the three VOs studied were determined at the Castilla y León Regional Laboratory (LARECOM), in Spain, which is an accredited laboratory for fuel analysis. The results of these analyses, together with the standard procedures applied to determine each property, are shown in Table 1. Studying the physicochemical properties is important since these affect the combustion process. Elemental analysis is used to calculate the excess air required for combustion, and both the viscosity and density of the fuel determine the atomisation process. 
VOs are triacylglycerols whose fatty acids profile displays different substitution patterns with regard to length, degree of unsaturation and chain geometry of the hydrocarbon chains. The fatty acid composition of each VO is unique, affects the state of aggregation, and impacts the physical properties such as density, viscosity and heating value [23, 25-28]. As a result, fatty acid composition determines the VO’s behaviour during the combustion process, as recently shown by [28] when analysing the combustion characteristics of crude vegetable oil droplets. The chemical composition of the VOs studied was determined using gas chromatography, in accordance with ISO 12966. The percentages calculated of each fatty acid for SyO, SfO and RpO are shown in Table 2. As can be seen, the main unsaturated fatty acids were oleic, O (C18:1), linoleic, L (C18:2), linolenic, Ln (C18:3) and for the saturated fatty acids, palmitic, (C16:0) and stearic (C18:0). For SfO and SyO, linoleic fatty acid was the main component (62.5 and 50.1\%, respectively) while RpO had the highest percentage of oleic fatty acid (64.4\%). Ln fatty acid was detected in SyO and RpO, (6\% and 8.5\%, respectively). A low content in saturated fatty acids was obtained in all the VOs analysed, ranging from $7.2 \%$ to $16.1 \%$.

\section{Combustion equipment and procedure}

The experimental facility used to burn the VOs was designed by the authors and was composed of several clearly distinguishable elements shown in Table 3. The burner feed system consists of two tanks and a network of valves and pipes enabling the fuel to be changed easily without turning off the facility. Each tank was equipped with a heating device, controlled by a thermostat, which allows the sample temperature to be adjusted.

In the commercial burner used in this work (AR-CO model BR5), the fuel flow was mixed with primary air through a rotary vane compressor, forming a vegetable oil fuel- 
air emulsion. With this technology, an almost perfect blend of air and fuel, and good pulverization in the nozzle was achieved, enabling it to burn liquid fuels that cover a wide range of viscosities.

Combustion was carried out in a boiler connected to a chimney which contains a flap valve that allows the back-pressure inside as well as the chimney draught to be adjusted. The device is also equipped with a gas analyser, TESTO 350, with a probe inserted at a central point of the interior section of the chimney. This device measures the concentration in flue gas of $\mathrm{O}_{2}$, in percentage, and those of $\mathrm{CO}, \mathrm{NO}_{\mathrm{x}}, \mathrm{SO}_{2}$ and $\mathrm{CxHy}$ in ppm. as well as the flue gas temperature and input temperature of combustion air.

Combustion of the VOs was performed following a technique [22-24] which involved the following stages; starting up the burner with diesel fuel until steady state was achieved, feeding the VO fuel, adjusting the conditions of each assay, and measuring the emissions and temperatures using the gas analyser. Finally, the pipes were cleaned with diesel fuel and the burner was turned off.

The experiments were carried out in similar weather conditions so as to reduce the possible impact of room temperature and environmental humidity on the combustion results. All of the VOs studied were pre-heated to $40{ }^{\circ} \mathrm{C}$ and the fuel injection pressure in the emulsion was kept at $1 \times 10^{5} \mathrm{~Pa}$.

The gases produced as a result of the combustion process are $\mathrm{CO}_{2}, \mathrm{H}_{2} \mathrm{O}$ and $\mathrm{SO}_{\mathrm{x}}$ (if the fuel contains sulphur compounds). Also formed are the so-called unburnt gases, CO and $\mathrm{CxHy}$, which are the result of incomplete combustion, as well as nitrogen oxides, $\mathrm{NO}_{\mathrm{x}}$, which depend on the amount of nitrogen in the fuel and the flame temperature. The concentrations of pollutant gases in flue gases are strictly regulated by law, and must be $\leq 130$ ppm for $\mathrm{CO}[29], \leq 150$ ppm for $\mathrm{NO}_{\mathrm{x}}[30]$ and $\leq 134 \mathrm{ppm}$ for $\mathrm{SO}_{\mathrm{x}}[30]$. 
An imperfect fuel-air blend is the main cause of the formation of unburnt species. In an effort to minimise this problem, excess air is used in industrial and domestic boilers. As a result, a certain amount of oxygen $\left(\% \mathrm{O}_{2}\right)$ is also found in the combustion gases. With this value, two characteristic parameters of combustion were calculated: excess air index $(\lambda)$, and $\mathrm{CO}_{2}$ in the flue gas. The three parameters are related through the expression:

$$
\begin{gathered}
1+\alpha \frac{\left[\mathrm{O}_{2}\right]}{21-\left[\mathrm{O}_{2}\right]}=\lambda=\alpha\left(\frac{\left[\mathrm{CO}_{2}\right]_{\text {max }}}{\left[\mathrm{CO}_{2}\right]_{\text {real }}}-1\right)+1 \\
{[\alpha=0.9429(\mathrm{SyO}), 0.9428(\mathrm{SfO}), 0.9424(\mathrm{RpO})]}
\end{gathered}
$$

with $\alpha$ being a coefficient characteristic of each vegetable oil fuel, given by the relationship between the volume of stoichiometric flue gas and the volume of stoichiometric air. Both values are calculated taking into account the elemental composition of each VO fuel, following a procedure described in ASHRAE [31]. $\left[\mathrm{CO}_{2}\right]_{\max }$ is the concentration in flue gas in a stoichiometric combustion, and $\left[\mathrm{CO}_{2}\right]_{\text {real }}$ is the concentration in flue gas in a combustion with excess air. $\left[\mathrm{CO}_{2}\right]$ and $\left[\mathrm{O}_{2}\right]$ are expressed as a percentage.

In order to assess combustion quality, emissions of $\mathrm{CO}_{2}, \mathrm{CO}, \mathrm{NO}_{\mathrm{x}}$ and $\mathrm{CxHy}$ were analysed and combustion performance, $\square$, was calculated, per unitof mass, in accordance with the procedure described in ASRHAE [23,31] (Eq. 2):

$$
\eta=100 \cdot\left(\frac{L H V-\text { Sensible heat loss }}{L H V}\right)=\left(1-\frac{C p_{g} \cdot m_{g} \cdot\left(t_{g}-t_{a}\right)}{L H V}\right) \cdot 100 \quad \text { Eq. } 2
$$

$t_{g}$ : flue gas temperature at the exit of the heating device $\left({ }^{\circ} \mathrm{C}\right)$.

$t_{a}$ : input temperature of combustion air $\left({ }^{\circ} \mathrm{C}\right)$.

$C p_{g}$ : specific heat of flue gases, at constant pressure, for $t_{g}\left[\mathrm{~kJ} \cdot\left(\mathrm{kg} \cdot{ }^{\circ} \mathrm{C}\right)^{-1}\right]$. $m_{g}: \mathrm{kg}$ of dry flue gases produced for combustion with excess air per kg of fuel $\left(\mathrm{kg} \cdot \mathrm{kg}_{\text {fuel }}{ }^{-1}\right)$.

$L H V$ : low heating value $\left(\mathrm{kJ} \cdot \mathrm{kg}^{-1}\right)$ 


\section{Experimental design}

In this work, three factors were modified in each combustion experiment: the type of vegetable oil, the fuel flow; and the secondary airflow rates. For each VO, three fuel flow rates (C1, C3 and C6) and three airflows (Amin, Amid and Amax) were studied, and a total of 27 different conditions were analysed. Each test was repeated a different number of times, and 75 experiments were carried out in all (results available in the Supporting Information). Table 4 shows the factors with their corresponding levels. Five different variables were studied for each experiment, combustion performance and concentration of $\mathrm{CO}_{2}, \mathrm{CO}, \mathrm{NO}_{\mathrm{x}}$ and $\mathrm{CxHy}$ in flue gases.

Fuel flows were determined with a flowmeter, hooked up to the fuel tank that fed the burner. Airflows were determined with a flow nozzle TG-40 (TECNER Engineering model). The values obtained are shown in Table 5.

\section{Statistical Analysis}

First, a descriptive study of the variables involved in the combustion process was performed using a principal component analysis (PCA) technique. PCA seeks optimal dimensionality reduction by considering linear combinations of the original variables (principal components) which capture the maximum possible underlying information in those variables. The joint representation (biplot) of the component weights, together with the coordinates (scores) of the optimally projected individuals provides a simple way to visualize higher dimensional data sets. Furthermore, correlations among variables can also be easily visualized in the biplot. We applied PCA to the five output combustion variables: performance, $\mathrm{CO}_{2}, \mathrm{CO}$, $\mathrm{NOx}$ and $\mathrm{CxHy}$ emissions, together with four other physicochemical variables: viscosity, LHV, monounsaturated fatty acids, MUFA and L, which measure different features of the VOs. 
After this simple descriptive study of PCA, a more inferential technique, ANOVA, was used to analyse the dependence of three categorical variables, VO type, and airflow as well as fuel flow levels on the combustion response variables. ANOVA is a widely applied statistical methodology to explore variability in the response variable by considering partitions of that variability into appropriate sums of squares. These sums of squares serve to test the significance of the considered effects, and their interactions, on the five response variables analysed. Statistical analyses were performed by using $\mathrm{R}$ statistical programming language and Statgraphics Centurion 18 software.

\section{Results and discussion}

\subsection{Principal Component Analysis (PCA)}

PCA was applied on the nine numerical variables mentioned above: combustion performance, ( $\mathrm{CO}_{2}$, $\mathrm{CO}$, NOx, CxHy) emissions, viscosity, LHV, MUFA, and L. We only focus on the first two principal components. The associated biplot is shown in Figure 1. Each individual experiment is represented by a point, and each variable by an arrow.

The three charts in Figure 1 also highlight different levels of the categorical variables analysed: VO (a), airflow (b) and fuel flow (c), by coding these levels with different colours in the biplot. Variables pointing in the same directions in the plot show clear positive correlations between

- (Viscosity, MUFA) and CxHy

- $\quad$ LHV and L

- $\quad \mathrm{CO}_{2}$ and NOx 
A negative correlation between variables, pointing in opposite directions is observed between

- $\quad$ viscosity with (L and LHV)

- $\quad\left(\mathrm{CO}_{2}, \mathrm{NOx}\right)$ and $\mathrm{CO}$.

The observed correlations between viscosity and fatty acids content can be explained by considering that viscosity is the result of the forces of cohesion between the molecules of the fluid, with these being greater the more linear the fatty acid chain is. The MUFA chains, with only one cis carbon-carbon double bond, barely alter the fatty acid zig-zag arrangement, giving rise to intense inter- and intramolecular forces between adjacent hydrocarbonated chains, mainly van der Waals dispersion forces and $\pi-\pi$ interactions. In contrast, the chains of linoleic fatty acid with two cis carbon-carbon double bonds, display angular shapes increasing the distance between adjacent hydrocarbonated chains and reducing these interactions. From Table 2, it can be seen that RpO exhibits the biggest percentage of MUFA (mainly oleic FA) and is the one with the highest viscosity. On the other hand, SfO is the one that contains the highest percentage of linoleic FA and the lowest viscosity.

Furthermore, high viscosity values give rise to poor fuel atomization, incomplete combustion and unburned hydrocarbon formation, which could explain the positive correlation between CxHy and viscosity. As regards the negative correlation between viscosity and the lower heating value (LHV), San José et al. [23] observed that the LHV of several VOs, rich and poor in unsaturated fatty acids, increased as the DU (Table 2) increased, contrary to viscosity. In contrast, direct correlation between LHV and viscosity in FAMEs (biodiesel) has been established by some researchers [25-28], evidencing the different behaviour of VOs with regard to the FAMEs as a result of the latter's greater molecular complexity. 
Moreover, by examining the relative positions of the scores corresponding to all of the analysed experiments in the two-dimensional biplot (figure 1a), it can be seen that in most of the tests performed, SyO provided relatively high values in combustion performance, coupled with relatively low $\mathrm{CO}$ emissions. As regards $\mathrm{CO}_{2}, \mathrm{CO}$ and $\mathrm{NO}_{\mathrm{x}}$ emissions, the groups of scores whose colour codes the type of VO are distributed parallel to the axis marked by $\mathrm{CO}$ and $\mathrm{CO}_{2}-\mathrm{NOx}$, which shows there is no clear correlation between these emissions and the physicochemical properties analysed. As for the biplot in Figure 1b shows that fuel flow emerges as quite an important factor with regard to explaining combustion characteristics. Most of the experiments performed with the fuel flow rate at level C1 are associated to relatively large CO emissions and relatively low combustion performances. In contrast, in most of the assays carried out in conditions C3 and C6, good combustion performances, low emissions of CO and relatively high NOx emissions were obtained, with these values always being below those permitted by legislation. As regards airflow, a greater dispersion of results was obtained, as can be seen in Figure 1c.

\subsection{Analysis of variance (ANOVA)}

ANOVA was performed to identify the most significant factors in the combustion variables: combustion performance and ( $\mathrm{CO}$, $\mathrm{NOx}$ and $\mathrm{CxHy}$ and $\left.\mathrm{CO}_{2}\right)$ emissions in flue gas, obtained in the different combustion tests. The associated results are shown below, where one table for each of the five considered response variables is provided (Tables 6-10). The significance level of each factor, type of VO, airflow and fuel flow, was characterized in terms of p-values. It is important to note that most of the main factors and interactions between them are significant at standard 0.01 and 0.05 levels. In fact, very small p-values are found in almost all the cases, with the sole exception of the variable CxHy, for which a p value $=0.4821(>0.05)$ was observed for the airflow 
factor. For this reason, this factor cannot be considered statistically significant in this case.

Due to the significance of most of the interaction effects, it is essential to analyse interaction plots (Figures 2-6). These graphs show the effect of each factor and its combinations of values on the variable considered and help to establish the optimal operating conditions for the burner. Optimising the combustion process involves using minimum excess air, obtaining the highest combustion performance and pollutant emissions (CO, NOx and CxHy) below the legally established limits.

Figure 2 shows the variation in the mean percentages of $\mathrm{CO}_{2}$ obtained in the combustion tests, depending on airflow (right) and fuel flow (left) for the different types of VOs. The greatest variability observed in the mean levels of $\mathrm{CO}_{2}$ for the various fuel flows, compared to the airflow, would indicate a greater influence of fuel flow in the concentration of $\mathrm{CO}_{2}$ in flue gases. This might be explained by taking into account that the control parameters used in the burner offer a different variation for the fuel flow than for the airflow. Thus, there is a greater difference between the fuel flow values than between the airflow values, as can be seen in Table 5. Changing from C1 to C3 entails an increase in fuel flow of between $30 \%$ and $40 \%$ depending on the VO used. This increase varies between 10 and 17\% from C3 to C6. In contrast, when changing from Amin to Amid and from Amid to Amax, increases in airflow were substantially lower and varied around 5\% and $8 \%$, respectively.

Variations of combustion performance with regard to fuel flows and airflows are shown in Figure 3. For this variable, an improvement could be seen as the fuel flow increased and the airflow was reduced. The relationship between airflow and performance can be explained by considering that sensible heat losses in flue gases decrease as the airflow is reduced (see Eq. 2). 
Figures 2 and 3 clearly show how for the three VOs studied, the best combination for emissions of $\mathrm{CO}_{2}$ and performance is $\mathrm{C6} / \mathrm{Amin}$, with soya oil, SyO, exhibiting the best performance in the emulsion burner, with regard to the two variables represented. This result evidences the impact of VO fatty acid content on combustion performance. A high percentage of just one type of fatty acid (oleic for RpO and linoleic for SfO) does not appear to be suitable for good combustion, whereas soya oil, with a more balanced proportion in saturated fatty acids (SFA) and unsaturated fatty acids (oleic, linoleic and linolenic fatty acids), performs better. A similar result was seen by [32] when studying the relationship between fatty acid composition of biodiesel on engine performance and emissions.

As expected, the interaction plots for $\mathrm{CO}$ emissions (Figure 4) showed that, as with $\mathrm{CO}_{2}$ emissions, these are more affected by fuel flow than by airflow. Moreover, tests conducted with fuel flows C3 and C6, at any airflow, gave remarkably low CO emissions, $\mathrm{CO} \leq 41 \mathrm{ppm}$, which are values well below the $130 \mathrm{ppm}$ established as the most restrictive current legislation [29].

Emissions of NOx were seen to increase with fuel flow and airflow, with the lowest emissions being obtained for C1 and Amin (Figure 5). Given that the nitrogen content of VOs is virtually negligible, these emissions are mainly formed as a result of the decomposition of nitrogen in air and its subsequent oxidation with oxygen. This process is furthered by high flame temperatures (favoured at high fuel flows) and long dwell times in the combustion chamber (favoured at low airflows), which would explain the values obtained.

A comparative analysis of interaction plots for $\mathrm{CO}, \mathrm{NO}_{\mathrm{x}}$ (Figures 4 and 5) reveals that, as $\mathrm{NO}_{\mathrm{x}}$ emissions decreased, $\mathrm{CO}$ emissions increased. This result can be explained considering that the conditions favouring complete combustion and, therefore, low CO 
emissions, are a high flame temperature and long dwell times in the combustion chamber which are, in fact, what triggers thermal NOx formation. It is important to highlight that the NOx levels obtained in all the experimental conditions assayed were under 55 ppm, well below the 150 ppm which is the most restrictive limit set by current legislation [30].

For CxHy emissions, the greater influence of the type of VO is clearly visible in Figure 6, which also shows there is no clear trend in these emissions with regard to fuel flow and airflow. For SyO, flows C1 and C6 gave rise to the lowest emissions, whereas for SfO and RpO these are given by flows $\mathrm{C} 1$ and C3. Formation of CxHy is related to incomplete combustion, probably due to poor atomization of the fuel, which ultimately depends on the physicochemical properties and fatty acids composition of each VO studied.

\section{Conclusions}

In this paper, PCA and ANOVA were applied to the combustion results of an emulsion burner fuelled with refined vegetable oils in order to establish the optimal operating conditions that provide the highest combustion performance and pollutant emissions below the limits established by law. On the basis of the results, the following findings may be put forward:

From PCA, an interesting positive correlation between CxHy and (viscosity and MUFA) as well as a negative correlation between viscosity with (L and LHV) was observed. According to the results obtained from ANOVA, the type of vegetable oil, the control parameters of the burner (airflow and fuel flow rates) together with most of their interactions, are statistically significant for four dependent variables studied, performance combustion, and $\left(\mathrm{CO}_{2}, \mathrm{CO}, \mathrm{NOx}\right)$ emissions. However, for $\mathrm{CxHy}$ 
emissions, airflow rate were not seen to have a significant effect. From PCA and the interaction plots, it is clear that However, in all the tests carried out, NOx emissions remained well below the current legal limits, and fairly low CO values were obtained. In summary, the optimal conditions in terms of performance and pollutant emissions are those in which the burner works with the maximum fuel flow (C6) and minimum airflow (Amin), with SyO fuel providing the best results. This work demonstrates that vegetable oils are possible alternative fuels for heating purposes and may be used in a commercial emulsion burner without any need to modify it.

Supporting Information: The following are available: Table S1. Variations of combustion results with Fuel flow and Secondary Airflow rates of the three vegetable oils studied.

\section{Acknowledgments}

The financial support for this work provided by the Spanish government (Ministry of Finance and Competitiveness, grant MTM2017-86061-C2-1-P) and the Regional Government of Castilla y Leon (ERDF, VA272P18, grants VA005P17 and VA002G18), is gratefully acknowledged. 


\section{References}

(1) BP Statistical Review of World Energy 2018. http://www.bp.com (accessed March 2019).

(2) For a review see: N.A. Negm, M.T.H. Abou Kana, M.A. Youssif, M.Y. Mohamed, Biofuels from Vegetable Oils as Alternative Fuels: Advantages and Disadvantages. Surfactants in Tribology 51 (2017) 289-368.

(3) For recent reviews see: (a) M. Erdem Gunay, L. Turker, N. Alper Tapan, Significant parameters and technological advancements in biodiesel production systems, Fuel 250 (2019) 27-41 and (b) R. Shan, L. Lu, Y. Shi, H. Yuan, J. Shi, Catalysts from renewable resources for biodiesel production, Energy Conversion and Management 178 (2018) 277-289.

(4) M. Zhang, H. Wu, Effect of major impurities in crude glycerol on solubility and properties of glycerol/methanol/bio-oil blends, Fuel 159 (2015) 118-127.

(5) J.A. López-Sastre, J. San José-Alonso, C. Romero-Ávila, E.J. López Romero, C. Rodríguez Alonso, A study of decrease in fossil $\mathrm{CO}_{2}$ emissions of energy generation by using vegetable oils as combustible, Build. Environ. 38 (2003) 129-133.

(6) J.F. San José-Alonso, C. Romero-Ávila, J.A. López-Sastre, E.J López Romero, C. Izquierdo-Iglesias, Using mixtures of diesel and sunflower oil as fuel for heating purposes in Castilla y León, Energy 30 (2005) 573-582.

(7) J.F. San José-Alonso, J.A. López-Sastre, E. Rodríguez-Duque, E.J. López Romero, C. Romero-Avila, Combustion of Soya Oil and Diesel Oil Mixtures for Use in Thermal Energy Production, Energy Fuels 22 (2008) 3513-3516. 
(8) J. San José-Alonso, J.A. López-Sastre, C. Romero-Ávila, E.J. López Romero, A note on the combustion of blends of diesel and soya, sunflower and rapeseed vegetable oils in a light boiler, Biomass Bioenergy 32 (2008) 880-886.

(9) J. San José-Alonso, J.A. López-Sastre, C. Romero-Ávila, E.J. López Romero, Combustion of rapeseed oil and diesel oil mixtures for use in the production of heat energy, Fuel Process. Technol. 87 (2006) 97-102.

(10) J.F. San José-Alonso, I. Gobernado-Arribas, S. Alonso-Miñambre, Study of combustion in residential oil burning equipment of animal by-products and derived products not intended for human consumption, Int. J. Energy Environ. Eng. 4 (2013) 113.

(11) T. Daho, G. Vaitilingom, O. Sanogo, Optimization of the combustion of blends of domestic fuel oil and cottonseed oil in a non-modified domestic boiler, Fuel 88 (2009) 1261-68.

(12) T.E. Jiru, B.G. Kaufman, K. E. Ileleji, D. R. Ess, H.G. Gibson, D.E. Maier, Testing the performance and compatibility of degummed soybean heating oil blends for use in residential furnaces, Fuel 89 (2010) 105-113.

(13) M. N. Mohd Jaafar, Y. A. Eldrainy, M. F. Mat Ali, W. Z. Wan Omar, M.F.A. Mohd Hizam, Combustion Performance Evaluation of Air Staging of Palm Oil Blends. Environ. Sci. Technol. 46 (2012) 2445-2450.

(14) C. Esarte, J. Delgado, Influence of Heating Oil Formulation on the Combustion and Emissions of Domestic Condensing Boilers Using Fossil Fuel and Renewable Fuel Mixtures, Energy Fuels 32 (2018) 10106-10113. 
(15) G. Vaitilingom, Ch. Perilhon, A. Liennard, M. Gandon, Development of rape seed oil burners for drying and heating, Industrial Crops Products 7 (1998) 273-279.

(16) T. Daho, G. Vaitilingom, O. Sanogo, S.K. Ouiminga, A.S. Zongo, B. Piriou, J. Koulidiati, Combustion of vegetable oils under optimized conditions of atomization and granulometry in a modified fuel oil burner, Fuel 118 (2014) 329-334.

(17) I.Oprea, I. Pîşă, L. Mihăescu, T. Prisecaru, G. Lăzăroiu, G. Negrean, Research on the combustion of crude vegetable oils for energetic purposes, Environ. Eng. Manag. J. 8 (2009) 475-482.

(18) G. A. Holt, J. D. Hooker, Gaseous emissions from burning diesel, crude and prime bleachable summer yellow cottonseed oil in a burner for drying seed, cotton, Bioresour. Technol. 92 (2004) 261-267.

(19) V. Józsa, A. Kun-Balog, Stability and emission analysis of crude rapeseed oil combustion, Fuel Process. Technol. 156 (2017) 204-210.

(20) V. Giovannoni, R.N. Sharma, R.R. Raine, Experimental Investigation of a SmallScale Combustion Chamber fueled with Vegetable Oil, Combustion Science and Technology (2019) 1-20, https://doi.org/10.1080/00102202.2019.1565492.

(21) J. San José, C. Romero-Ávila, L.M. San José Hernández, A. Al-Kassir, Characterizing biofuels and selecting the most appropriate burner for their combustion, Fuel Process Technol. 103 (2012) 39-44.

(22) J. San José, M.A. Sanz-Tejedor, Y. Arroyo, Effect of fatty acid composition in vegetable oils on combustion processes in an emulsion burner, Fuel Process. Technol. 130 (2015) 20-30. 
(23) M. A. Sanz-Tejedor, Y. Arroyo, J. San José, Influence of Degree of Unsaturation on Combustion Efficiency and Flue Gas Emissions of Burning Five Refined Vegetable Oils in an Emulsion Burner, Energy Fuels 30 (2016) 7357-7366.

(24) J. San José, M. A. Sanz-Tejedor, Y. Arroyo, Spray characteristics, combustion performance and palm oil emissions in a low-pressure auxiliary air fluid pulverization burner, Energy Fuels 32 (2018) 11502-11510.

(25) G. Knothe, Dependence of biodiesel fuel properties on the structure of fatty acid alkyl esters, Fuel Process. Technol. 86 (2005) 1059-1070.

(26) A. Demirbas, Relationships derived from physical properties of vegetable oil and biodiesel fuels, Fuel 87 (2008) 1743-48.

(27) G. Martínez, N. Sánchez, J.M. Encinar, J. F. González, Fuel properties of biodiesel from vegetable oils and oil mixtures. Influence of methyl esters distribution, Biomass Bioenergy 63 (2014) 22-32.

(28) H.Y. Nanlohy, I.N.G. Wardana, N. Hamidi, L.Yuliati, T. Ueda, The effect of $\mathrm{Rh}^{3+}$ catalyst on the combustion characteristic of crude vegetable oil droplet, Fuel 220 (2018) 220-232.

(29) RD 815/2013, of 18 October, approving the regulations for industrial emissions, and application of Law 16/2002 of 1 July, on the integrated prevention and control of pollution, BOE 251 of 2013. https://www.boe.es/eli/es/rd/2013/10/18/815 (accessed May 2019).

(30) RD 1042/2017, of 22 December, on the limitation of emissions into the atmosphere of certain contaminating agents from medium size combustion facilities and updating 
annex IV of Law 34/2007, of 15 November, on air quality and air protection. https://www.boe.es/eli/es/rd/2017/12/22/1042/con (accessed May 2019).

(31) In ASHRAE Handbook Fundamentals. Atlanta GA ed. 2013, chapter 28.

(32) S. Deshmukh, R. Kumar, K. Bala, Microalgae biodiesel: A review on oil extraction, fatty acid composition, properties and effect on engine performance and emissions, Fuel Process. Technol. 191 (2019) 232-247

Corresponding Authors

*Tel.: +34983184420. E-mail: yarroyo@eii.uva.es (Y.A.).

*Tel.: +34983184418. E-mail: atejedor@eii.uva.es (M.A.S.-T.).

NOTES

The authors declare no competing financial interest. 
(a) Vo

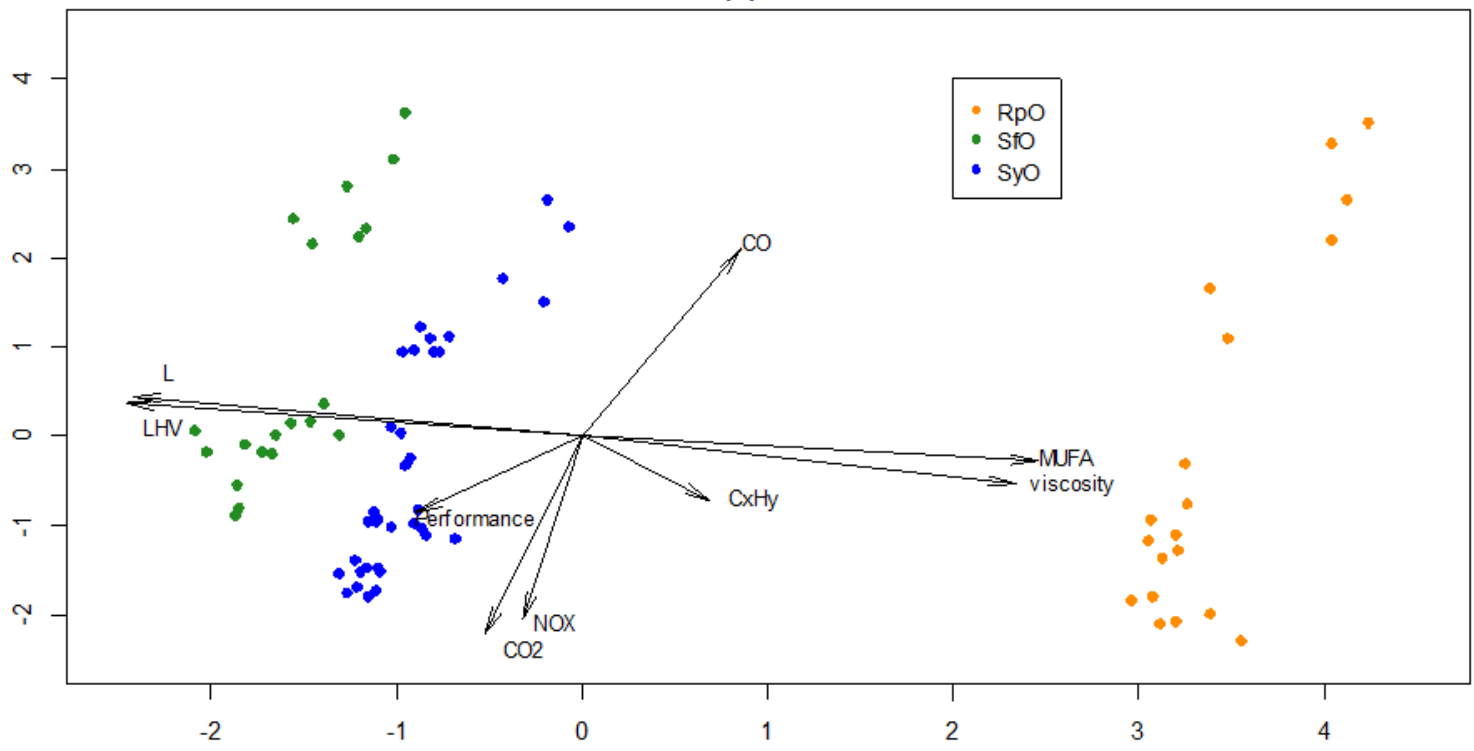

(b) Fuel flow

(c) Air flow
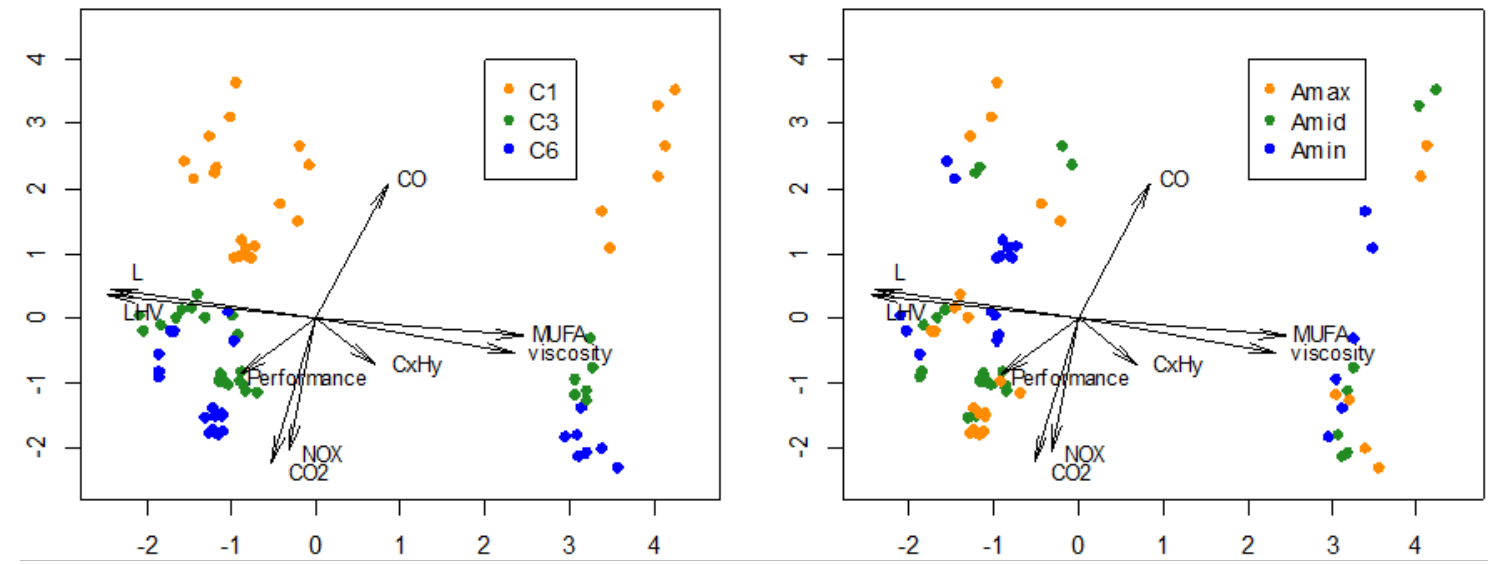

Figure 1: Two-dimensional PCA biplots (the x-axis corresponds to the first PCA component and the y-axis to the second) with different code levels: (a) VO, (b) fuel flow (c) airflow. The variability explained by the two first PCA components is $73.58 \%$. 

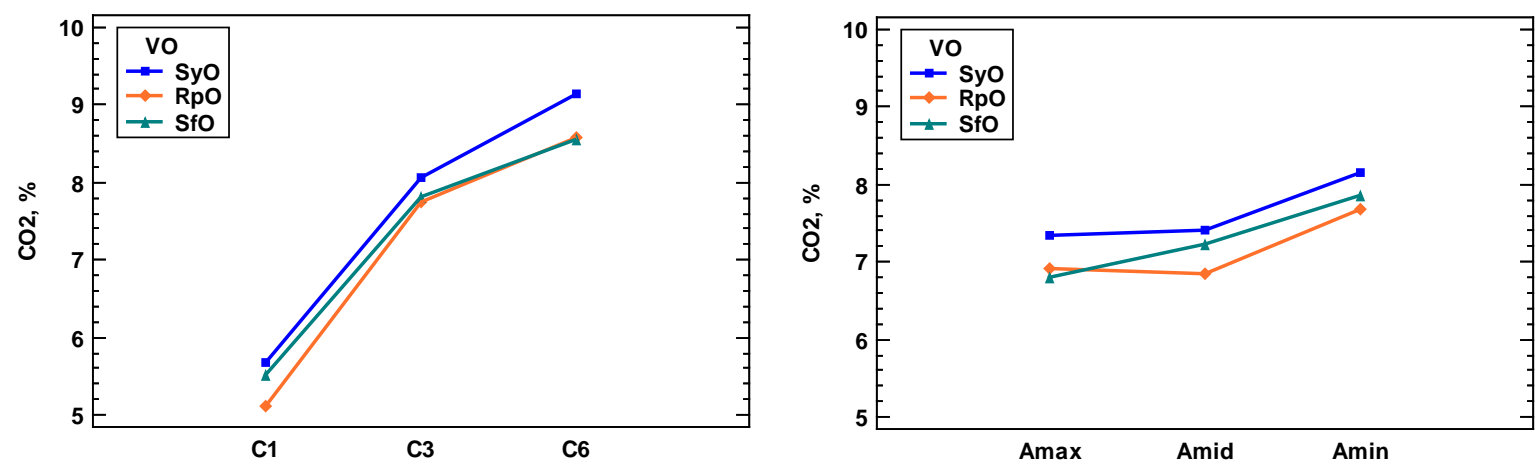

Figure 2. Interaction plots of the variability of $\mathrm{CO}_{2}$, in \%, with the fuel flow (left) and airflow factors (right) for each vegetable oil. 

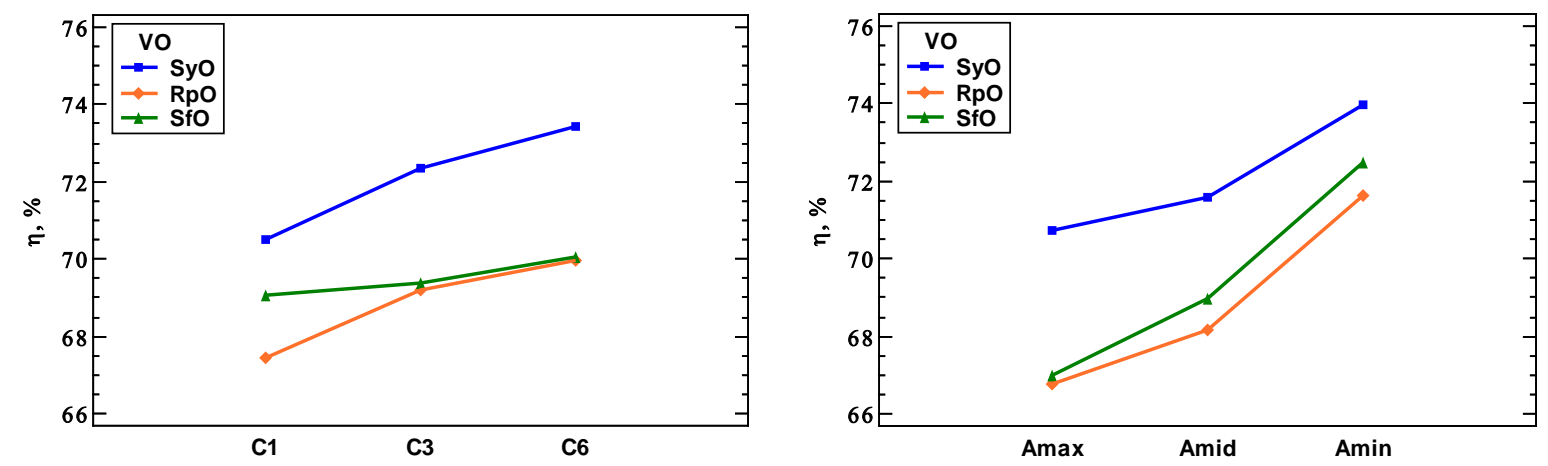

Figure 3. Interaction plots of the variability in combustion performance, in \%, with the fuel flow (left) and airflow factors (right) for each vegetable oil. 

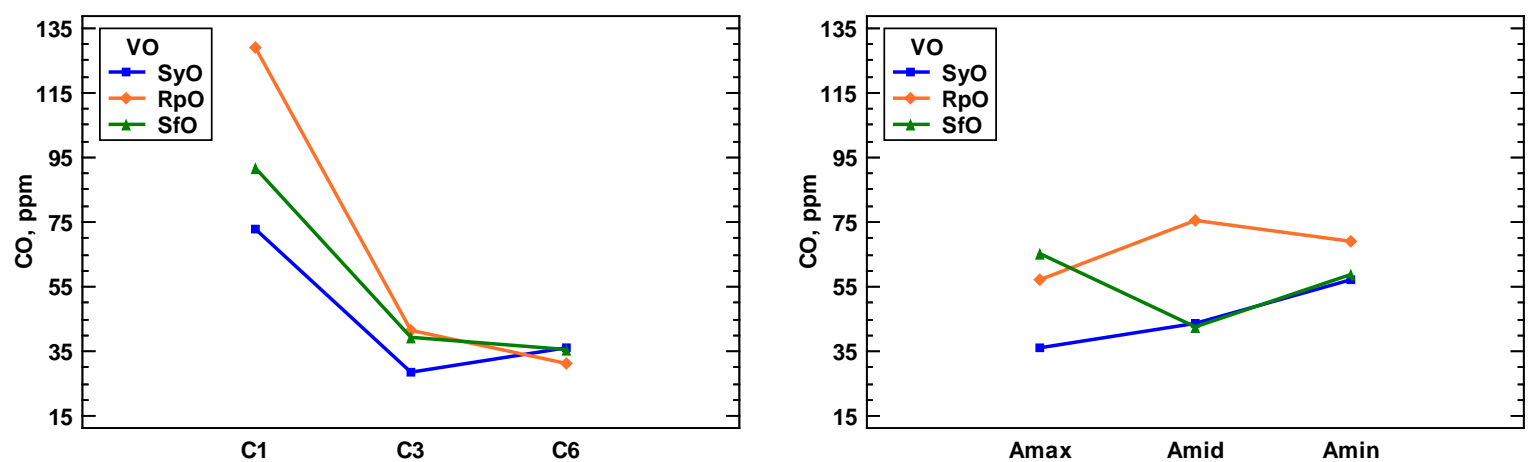

Figure 4. Interaction plot of the variability of CO, in ppm, with the fuel flow (left) and airflow factors (right) for each vegetable oil. 

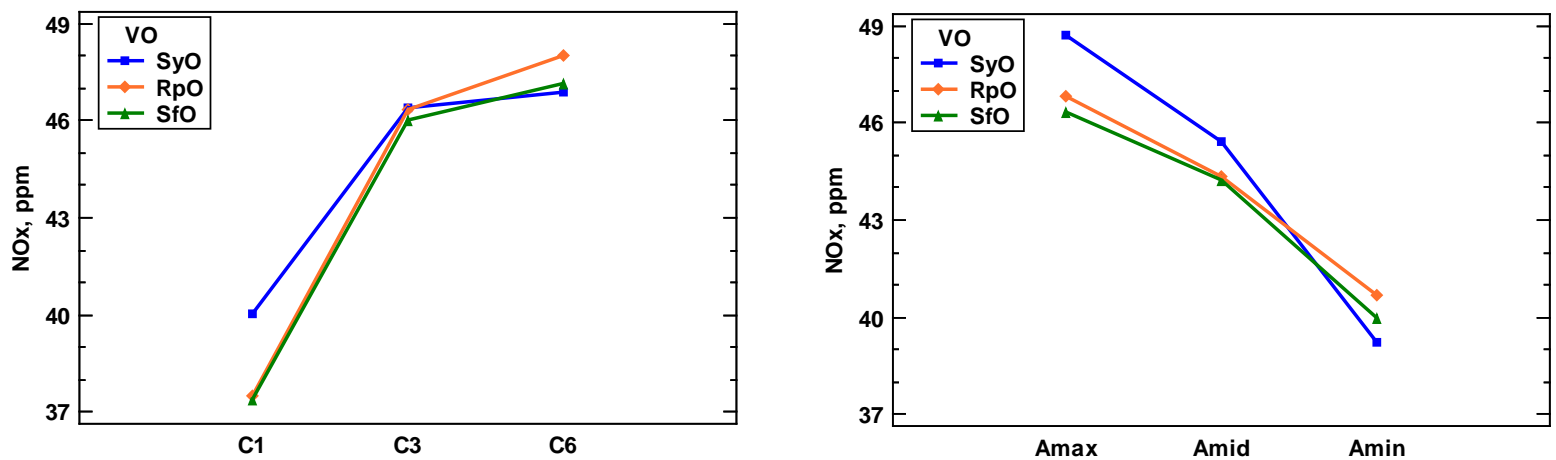

Figure 5. Interaction plot of the variability of NOx emissions, in ppm, with the fuel flow (left) and airflow (right) factors for each vegetable oil. 

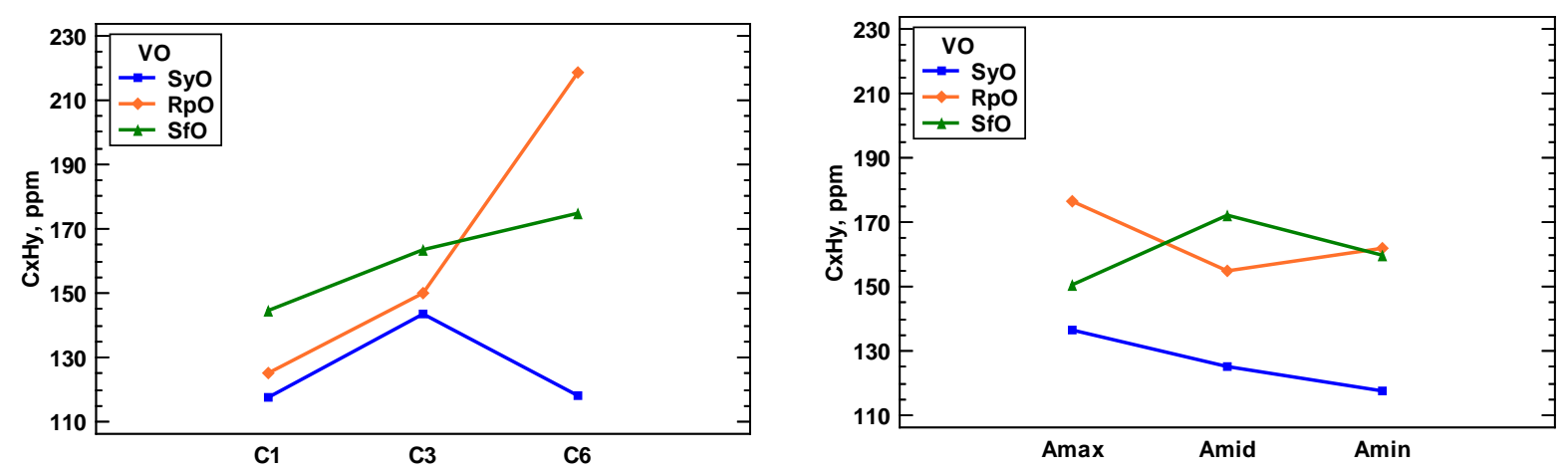

Figure 6. Interaction plot of the variability of CxHy emissions, in ppm, with fuel flow (left) and airflow (right) factors for each vegetable oil. 
Table 1. Elemental analysis and physical characteristics of the refined vegetable oils studied.

\begin{tabular}{llllll}
\hline & Unit & SyO & SfO & RpO & Standard \\
\hline $\mathrm{C}$ & $\%\left(\mathrm{~m} \cdot \mathrm{m}^{-1}\right)$ & 77.3 & 77.4 & 76.9 & ASTM5291 \\
$\mathrm{H}$ & $\%\left(\mathrm{~m} \cdot \mathrm{m}^{-1}\right)$ & 11.2 & 11.2 & 11.3 & ASTM5291 \\
$\mathrm{N}$ & $\%\left(\mathrm{~m} \cdot \mathrm{m}^{-1}\right)$ & $<0.05$ & 0.07 & $<0.05$ & ASTM5291 \\
$\mathrm{S}$ & $\%\left(\mathrm{~m} \cdot \mathrm{m}^{-1}\right)$ & 0.04 & 0.03 & 0.04 & ASTM1552 \\
$\mathrm{O}^{\mathrm{a}}$ & $\%\left(\mathrm{~m} \cdot \mathrm{m}^{-1}\right)$ & 11.4 & 11.2 & 11.7 & - \\
Ash & $\%\left(\mathrm{~m} \cdot \mathrm{m}^{-1}\right)$ & 0.004 & 0.005 & 0.007 & EN 6245 \\
Humidity & $(\%)$ & 0.02 & 0.01 & 0.06 & ISO 662 \\
Acidity & $(\%)$ & 0.11 & 0.03 & 1.73 & ISO 660 \\
Density at $15^{\circ} \mathrm{C}$ & $\mathrm{kg} \cdot \mathrm{m}^{-3}$ & 922.3 & 922.3 & 919.9 & ISO 12185 \\
Density at 35 ${ }^{\circ} \mathrm{C}$ & $\mathrm{kg} \cdot \mathrm{m}^{-3}$ & 909.0 & 908.9 & 906.7 & ISO 12185 \\
Density at $60^{\circ} \mathrm{C}$ & $\mathrm{kg} \cdot \mathrm{m}^{-3}$ & 892.4 & 892.3 & 890.1 & ISO 12185 \\
Kinematic viscosity & $\mathrm{mm} \cdot \mathrm{s}^{-1}$ & 32.53 & 32.10 & 35.65 & ISO 3104 \\
at $40{ }^{\circ} \mathrm{C}$ & & & & & \\
Kinematic viscosity & $\mathrm{mm}{ }^{2} \cdot \mathrm{s}^{-1}$ & 7.79 & 7.65 & 8.01 & ISO 3104 \\
at 100 ${ }^{\circ} \mathrm{C}$ & $\mathrm{kJ} \cdot \mathrm{kg}^{-1}$ & 39,370 & 39,500 & 38,840 & ASTM 240 \\
H.H.V. & $\mathrm{kJ} \cdot \mathrm{kg}^{-1}$ & 36,990 & 37,120 & 36,440 & ASTM 240 \\
L.H.V. & & & & \\
\hline
\end{tabular}

${ }^{\text {a }}$ Estimated by difference. 
Table 2. Proportions $\left(\% \mathrm{~m} \cdot \mathrm{m}^{-1}\right)$, obtained by gas chromatography, of the different FAs in $\mathrm{SyO}, \mathrm{RpO}$ and $\mathrm{SfO}$.

\begin{tabular}{lllll}
\hline \multicolumn{1}{c}{ Fatty acid } & SyO & SfO & RpO \\
& & & & \\
\hline Miristic & C14:0 & 0.08 & 0.07 & 0.05 \\
Palmitic & C16:0 & 10.4 & 5.9 & 4.5 \\
Margaric & C17:0 & 0.09 & 0.04 & 0.06 \\
\hline Stearic & C18:0 & 4.2 & 4.3 & 1.6 \\
\hline Arachidic & C20:0 & 0.5 & 0.6 & 0.3 \\
Behenic & C22:0 & 0.6 & 0.8 & 0.4 \\
Lignoceric & C24:0 & 0.2 & 0.3 & 0.3 \\
Palmitoleic & C16:1 & 0.09 & 0.1 & 0.2 \\
\hline Oleic & C18:1 & 27.3 & 25.4 & 62.7 \\
\hline Gadoleic & C20:1 & 0.5 & 0.3 & 0.6 \\
\hline Linoleic & C18:2 & 50.1 & 62.5 & 19.3 \\
\hline Linolenic & C18:3 & 6.0 & 0.09 & 0.5 \\
DUa (\%) & & 146.1 & 151.1 & \\
\hline & & & & \\
\hline
\end{tabular}

${ }^{a}$ Degree of Unsaturation [\%MUFA (total monounsaturated fatty acids) $+(\% \mathrm{~L}) \cdot 2+$ (\%Ln) 3$]$ 
Table 3. Characteristics of the combustion facility elements and installation photography.

\begin{tabular}{|c|c|c|c|}
\hline \multicolumn{4}{|c|}{ Characteristics of each element } \\
\hline 1: Fuel feed tanks & 2: Burner & 3: Boiler & $\begin{array}{l}\text { 4: Chimney and } \\
\text { gas analyser }\end{array}$ \\
\hline $\begin{array}{l}\text { 316 L steel tanks } \\
\text { and 5L shut-off valve }\end{array}$ & $\begin{array}{l}\text { Power rating } 17-58 \mathrm{~kW} \\
\text { Fuel viscosity } 26 \text { to } 112 \\
\mathrm{~mm}^{2} \cdot \mathrm{s}^{-1} \text { at } 50^{\circ} \mathrm{C}\end{array}$ & $\begin{array}{l}42 \mathrm{~kW} \text { power } \\
\text { air-cooled } \\
\text { concentric-tube } \\
\text { boiler }\end{array}$ & $\begin{array}{l}\text { Testo } 350 \text { gas } \\
\text { analyser }\end{array}$ \\
\hline \multicolumn{4}{|c|}{ Adjustable variables } \\
\hline Fuel temperature & $\begin{array}{l}\text { Airflow } \\
\text { Fuel flow }\end{array}$ & $\begin{array}{l}\text { Chamber } \\
\text { temperature } \\
\text { Chamber over- } \\
\text { pressure }\end{array}$ & Initial calibration $^{\mathrm{a}}$ \\
\hline \multicolumn{4}{|c|}{ Measurement variables } \\
\hline Fuel flow $\left(L \cdot \mathrm{s}^{-1}\right)$ & Fuel injection pressure & $\begin{array}{l}\text { Chamber } \\
\text { pressure } \\
\text { Chamber } \\
\text { temperature }\end{array}$ & $\begin{array}{l}\text { Flue gas and } \\
\text { reference } \\
\text { temperatures } \\
\text { Emissions: } \mathrm{O}_{2}, \mathrm{CO}_{2} \\
\text { in \%; CO, } \mathrm{NOx}, \\
\text { SOx, CxHy in ppm }\end{array}$ \\
\hline
\end{tabular}

${ }^{\text {a }}$ Prior to each assay, the equipment was calibrated with the oxygen sensor, and in each new test the manufacturer's calibration certificate is obtained. 
Table 4. Factors with levels

\begin{tabular}{llll}
\hline Factors & Level 1 & Level 2 & Level 3 \\
\hline VO & SyO & SfO & RpO \\
Fuel flow rate & C1 & C3 & C6 \\
Airflow rate & $\mathrm{A}_{\text {min }}$ & $\mathrm{A}_{\text {mid }}$ & $\mathrm{A}_{\max }$ \\
\hline
\end{tabular}


Table 5: Fuel flow and airflow rates.

\begin{tabular}{llll} 
Fuel flow $\left(\mathrm{kg} \cdot \mathrm{h}^{-1}\right)$ & $\mathrm{C} 1$ & $\mathrm{C} 3$ & $\mathrm{C} 6$ \\
$\mathrm{SfO}$ & 4.92 & 6.89 & 8.10 \\
$\mathrm{SyO}$ & 5.38 & 6.90 & 7.56 \\
$\mathrm{RpO}$ & 5.12 & 7.23 & 8.21 \\
\hline Airflows $\left(\mathrm{kg} \cdot \mathrm{h}^{-1}\right)$ & $\mathrm{A}_{\min }$ & $\mathrm{A}_{\operatorname{mid}}$ & $\mathrm{A}_{\max }$ \\
& 160 & 166 & 180 \\
\hline
\end{tabular}


Table 6. ANOVA results for $\mathrm{CO}_{2}$.

\begin{tabular}{|l|l|l|l|l|l|l|}
\hline Factor & Sum of Square & DF $^{*}$ & Mean Square & F-ratio & P-value \\
\hline \multicolumn{7}{|c|}{ Analysis of variance for $\mathbf{C O}_{2}$} \\
\hline VO & 2.64086 & 2 & 1.32043 & 75.05 & 0.0000 \\
\hline airflow & 8.95371 & 2 & 4.47686 & 254.46 & 0.0000 \\
\hline fuel flow & 120.987 & 2 & 60.4936 & 3438.33 & 0.0000 \\
\hline VO*airflow & 0.491117 & 4 & 0.122779 & 6.98 & 0.0002 \\
\hline VO*fuel flow & 0.523182 & 4 & 0.130795 & 7.43 & 0.0001 \\
\hline airflow*fuel flow & 1.39186 & 4 & 0.347966 & 19.78 & 0.0000 \\
\hline VO*airflow*fuel flow & 1.07527 & 8 & 0.134409 & 7.64 & 0.0000 \\
\hline Error & 0.844507 & 48 & 0.0175939 & & \\
\hline Total & 146.17 & 74 & & & \\
\hline
\end{tabular}

* Degree of freedom 
Table 7. ANOVA results for combustion performance.

\begin{tabular}{|l|l|l|l|l|l|l|}
\hline Factor & Sum of Square & DF & Mean Square & F-ratio & P-value \\
\hline \multicolumn{7}{|}{ Analysis of variance for combustion performance } \\
\hline VO & 128.711 & 2 & 64.3553 & 448.62 & 0.0000 \\
\hline airflow & 217.59 & 2 & 108.795 & 758.41 & 0.0000 \\
\hline fuel flow & 47.2 & 2 & 23.6 & 164.52 & 0.0000 \\
\hline VO*airflow & 10.5173 & 4 & 2.62933 & 18.33 & 0.0000 \\
\hline VO*fuel flow & 8.43269 & 4 & 2.10817 & 14.70 & 0.0000 \\
\hline airflow*fuel flow & 5.32697 & 4 & 1.33174 & 9.28 & 0.0000 \\
\hline VO*air*fuel flow & 8.90074 & 8 & 1.11259 & 7.76 & 0.0000 \\
\hline Error & 6.88565 & 48 & 0.143451 & & \\
\hline Total & 427.27 & 74 & & & \\
\hline
\end{tabular}


Table 8. ANOVA results for CO

\begin{tabular}{|l|l|l|l|l|l|l|}
\hline Factor & Sum of Square & DF & Mean Square & F-ratio & P-value \\
\hline \multicolumn{7}{|c|}{ Analysis of variance for CO } \\
\hline VO & 4862.31 & 2 & 2431.16 & 89.78 & 0.0000 \\
\hline airflow & 929.709 & 2 & 464.854 & 17.17 & 0.0000 \\
\hline fuel flow & 53740.6 & 2 & 26870.3 & 992.32 & 0.0000 \\
\hline VO*airflow & 3787.48 & 4 & 946.869 & 34.97 & 0.0000 \\
\hline VO*fuel flow & 7122.37 & 4 & 1780.59 & 65.76 & 0.0000 \\
\hline airflow*fuel flow & 23150.7 & 4 & 5787.68 & 213.74 & 0.0000 \\
\hline VO*airflow*fuel flow & 5427.94 & 8 & 678.493 & 25.06 & 0.0000 \\
\hline Error & 1299.76 & 48 & 27.0782 & & \\
\hline Total & 114260 & 74 & & & \\
\hline
\end{tabular}


Table 9. ANOVA results for NOx

\begin{tabular}{|l|l|l|l|l|l|}
\hline Factor & Sum of Square & DF & Mean Square & F-ratio & P-value \\
\hline \multicolumn{7}{|c|}{ Analysis of variance for NOx } \\
\hline VO & 9.50985 & 2 & 4.75493 & 3.89 & 0.0273 \\
\hline airflow & 559.299 & 2 & 279.649 & 228.55 & 0.0000 \\
\hline fuel flow & 996.447 & 2 & 498.223 & 407.18 & 0.0000 \\
\hline VO*airflow & 27.5012 & 4 & 6.8753 & 5.62 & 0.0009 \\
\hline VO*fuel flow & 29.2882 & 4 & 7.32206 & 5.98 & 0.0005 \\
\hline airflow*fuel flow & 137.513 & 4 & 34.3781 & 28.10 & 0.0000 \\
\hline VO*airflow*fuel flow & 62.9207 & 8 & 7.86509 & 6.43 & 0.0000 \\
\hline Error & 58.7321 & 48 & 1.22359 & & \\
\hline Total & 2422.67 & 74 & & & \\
\hline
\end{tabular}


Table 10. ANOVA results for CxHy.

\begin{tabular}{|l|l|l|l|l|l|l|}
\hline Factor & Sum of Square & DF & Mean Square & F-ratio & P-value \\
\hline \multicolumn{7}{|c|}{ Analysis of variance for CxHy } \\
\hline VO & 19500.5 & 2 & 9750.26 & 21.04 & 0.0000 \\
\hline airflow & 686.613 & 2 & 343.306 & 0.74 & 0.4821 \\
\hline fuel flow & 17690.8 & 2 & 8845.38 & 19.09 & 0.0000 \\
\hline VO*airflow & 4016.59 & 4 & 1004.15 & 2.17 & 0.0869 \\
\hline VO*fuel flow & 20915.2 & 4 & 5228.81 & 11.28 & 0.0000 \\
\hline airflow*fuel flow & 2736.31 & 4 & 684.077 & 1.48 & 0.2241 \\
\hline VO*airflow*fuel flow & 18454.2 & 8 & 2306.77 & 4.98 & 0.0002 \\
\hline Error & 22242.9 & 48 & 463.393 & & \\
\hline Total & 130667 & 74 & & & \\
\hline
\end{tabular}

